\title{
Comprehensive Pharmacognostical Profile of Drynaria quercifolia (L.) J. Sm.
}

\author{
Research Article
}

\section{Sunil Kumar K N1*, Divya K G², Susikumar S3 , Abdul Kader S4, Senthilkumar M³}

\author{
1. Research Officer and Head, 2. Assistant Research Officer, 3. Lab technician, \\ Pharmacognosy Department, Siddha Central Research Institute, Arumbakkam, Chennai. \\ 4. Assistant Professor, Department of Plant Biology \& Plant Biotechnology, \\ Presidency College (Autonomous), Chennai. \\ 5. Assistant Professor, PG and Research Department of Botany, \\ Vivekanandha College of Arts and Sciences for Women (Autonomous), Elayampalayam, Tiruchengode.
}

\begin{abstract}
Pteridophytes are gaining importance as therapeutic agents due to the presence of various phytochemicals and their promising bioactivities. Drynaria quercifolia (L.) J. Sm., a Polypodiaceae member is endowed with numerous medicinal properties and finds wide usage in ethno as well as traditional medicines. The rhizome of $D$. quercifolia (L.) J. Sm. was subjected to macro-microscopic, physicochemical, phytochemical and HPTLC analysis to derive a standard for this drug. The microscopic detailing showed a wavy outline due to the presence of ridges and furrows and a broad ground tissue with diffusely arranged steles. The powdered drug showed trichomes, stellar tissue and silica crystals while the physicochemical and phytochemical screenings gave substantial values of different parameters. The rhizome extracts were subjected to HPTLC studies with Linomat 5 TLC applicator and diagnostic peaks were recorded under UV $254 \mathrm{~nm}, 366 \mathrm{~nm}$ and $620 \mathrm{~nm}$. The study put forward an exclusive identity profile of this medicinal rhizome.
\end{abstract}

Key Words: Epiphytic, Polypodiaceae, Standardization, Steles, Traditional Medicine.

\section{Introduction}

Drynaria, an ephiphytic fern genus belong to the family Polipodiaceae is represented by fifteen species in the world. Of these, D. quercifolia (L.) J.Sm. (syn. Podophyllum quercifolium) called as 'oak leaf ferns' or a 'basket fern' is distributed in Australia, China, India, Indonesia, Malaysia, Philippines, Thailand, Singapore and Srilanka in different habitats like rock crevices, along the soil boulders and very often on the tree trunks (1). In India this fern is distributed throughout various habitats (2). It is used in traditional medicinal systems like Ayurveda and folk medicines. Known as 'Asvakatri' in Ayurvedic medicine the rhizome, possessing bitter taste, anodyne, antiinflammatory, anti- bacterial and astringent properties, is used for the treatment of typhoid fever, dyspepsia, cephalagia, cough and phthisis (3).

This rhizome possesses immense medicinal properties and is used by various tribal communities world over. Among the tribals in South East Asia it is used in the preparation of antipyretic formulations (4). In Bangladesh it is used in treating chest pain, diabetes, debility, insanity, jaundice, malaria, spermatorrhoea,

\section{* Corresponding Author:}

\section{Sunil Kumar K N}

Research Officer and Head of Pharmacognosy Department,

Siddha Central Research Institute, Arumbakkam,

Chennai 600106, Tamil Nadu, India.

Email Id: kn.sunil@gov.in sleeping and urinary disorders (5-12). For the treatment of baldness the rhizome is used in Chinese medicines (13). In Tripura it is used for treating intestinal worms and stomachache (14). The tribals living in the ghat regions of India use this rhizome in treating ailments like bone fracture, cholera, fever, headache, jaundice, rheumatism and vomiting (15-19). Aattukal kilangu soup made from the rhizomes of $D$. quercifolia is served in the hill stations of Tamil Nadu (20).

As there is no comprehensive monographic standardization report of this raw drug the present study was taken up with the view to standardize the rhizome of Drynaria quercifolia (L.) J. Sm. with respect to macro-microscopic, physicochemical and HPTLC finger profiling for authentication and quality characterization of this highly medicinal rhizome.

\section{Materials and Methods}

\section{Collection and Identification of samples}

The fresh rhizomes were collected from Yercaud in Salem district, Tamil Nadu during September 2019. The sample was identified and authenticated at Pharmacognosy department, SCRI, Chennai. The rhizome was cleaned and portion of it was air-dried for further studies.

\section{Pharmacognostical Evaluation Macroscopic characterization}

The macroscopy of the rhizome was documented by Nikon COOLPIX5400 digital camera. The colour, odour and taste were also recorded (21). 


\section{Microscopic characterization}

For microscopy small pieces of rhizome were hand cut into transverse sections using sharp platinum blade, stained with safranine and photographed using Nikon ECLIPSE E200 trinocular microscope attached with Nikon COOLPIX5400 digital camera under bright field light. Magnifications were indicated by the scalebars (22).

\section{Powder characterization}

A portion of the rhizome was shade dried, powdered and passed through sieve no. 60, and preserved in airtight containers for powder microscopy. The powder was mounted in glycerine on a clean microscopic slide, observed under Nikon ECLIPSE E200 trinocular microscope magnified to $400 \mathrm{X}$ and diagnostic characters were photographed (22).

\section{Physico-chemical analysis}

The physico-chemical parameters like moisture content, total ash, acid insoluble ash, alcohol soluble extractive and water soluble extractive were determined as per standard methods (23).

\section{Primary phytochemical screening}

The preliminary phytochemical screening of the rhizome was done to find various phytoconstituents following standard procedures (24).

\section{High Performance Thin Layer Chromatography}

One gram of powdered samples was dissolved in $10 \mathrm{ml}$ ethanol and kept for cold percolation for $24 \mathrm{hrs}$ and filtered. $6 \mu 1$ and $9 \mu 1$ of the above samples were applied on a pre-coated silica gel F254 on aluminum plates to a band width of $7 \mathrm{~mm}$ using Linomat 5 TLC applicator. The plate was developed in toluene: ethyl acetate (10: 1). The developed plates were visualized in UV 254, $366 \mathrm{~nm}$ and then derivatised with vanillin sulphuric acid reagent and scanned under UV 254 and $366 \mathrm{~nm}$. $\mathrm{R}_{\mathrm{f}}$, colour of the spots and densitometric scan were recorded.

\section{Results Morphology}

The fresh fleshy rhizome is up to $18 \mathrm{~cm}$ in length and up to $8 \mathrm{~cm}$ in width. The dried rough rhizome is reddish brown in colour, irregular in shape and nearly flat and measures up to $12 \mathrm{~cm} \times 6 \mathrm{~cm} \times 2 \mathrm{~cm}$. It is covered by velvet like soft copper coloured scale leaves. Longitudinal wrinkles are visible and the inner cut surface is light reddish brown in colour; fracture splintery; no characteristic odour and bitter taste (Fig.1).

\section{Figure 1. Drynaria quercifolia rhizome}

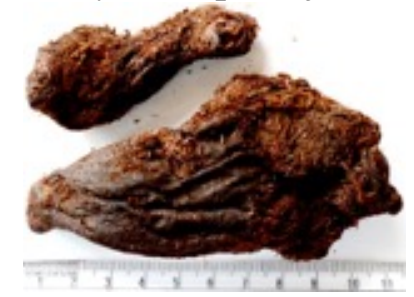

\section{Micro morphology}

\section{Anatomy}

Detailed TS of rhizome is wavy with ridges and furrows. An outermost single layered wavy epidermis covered with winged scales arising from the furrows and few multicellular trichomes are present. Scales are long, lanceolate with an elongated tapering apex. The epidermal cells are rectangular and filled with brownish contents. It is followed by a wide zone of ground tissue composed of thin walled compactly arranged rectangular parenchyma cells. The cells in the ground tissue also contain brownish content and steles are arranged diffusely in addition to the presence of few starch grains. The highly dissected protostele gives rise to numerous heteromorphic meristeles. Each stele is covered by a distinct layer of endodermis and pericycle. The meristeles have isolated elements of xylem surrounded by phloem. Xylem is composed of thick walled angular endarch metaxylem and exarch protoxylem elements surrounded by smaller phloem elements (Fig. 2 and 3).

\section{Figure 2. TS of Drynaria quercifolia rhizome}

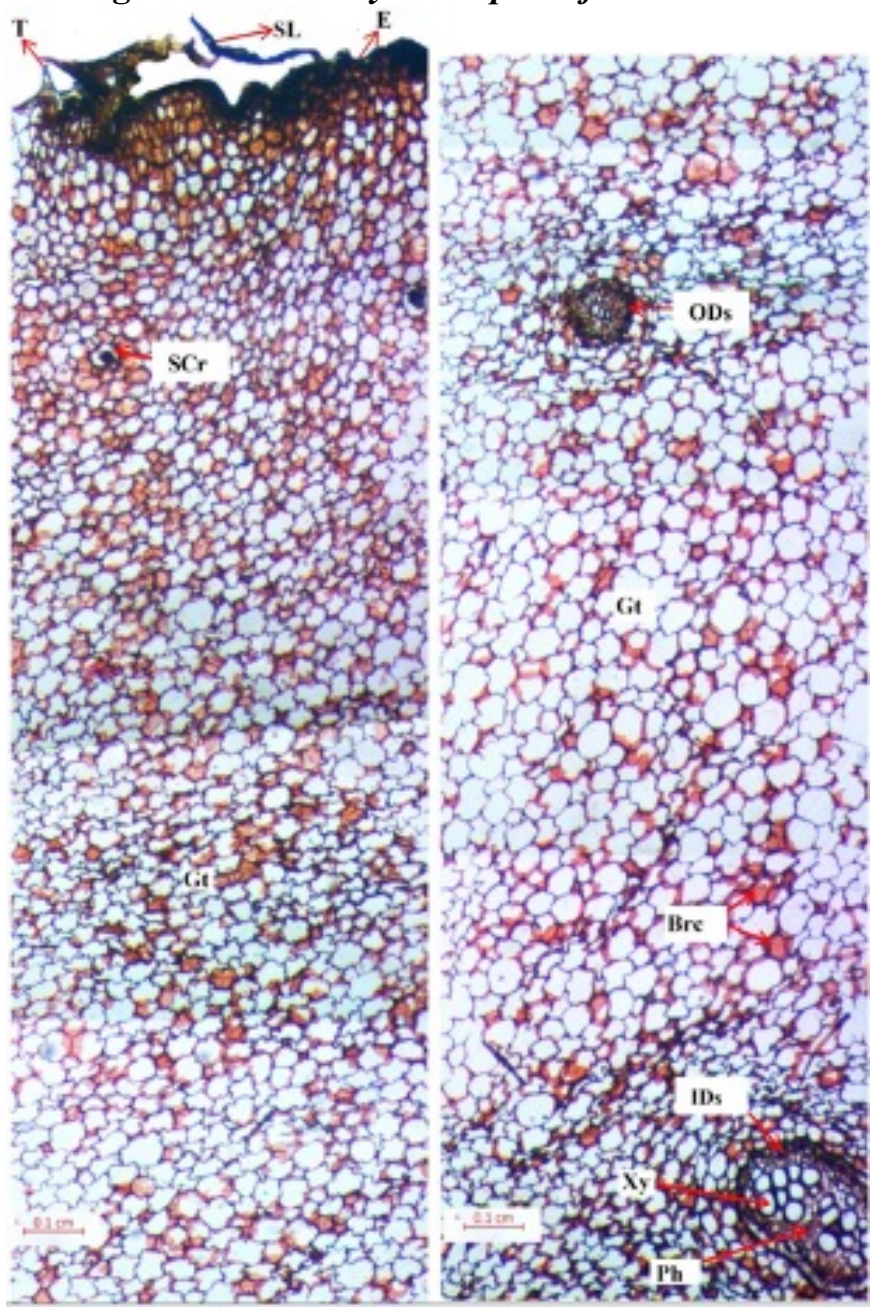

Brc- Brownish content; E- Epidermis; Gt- Ground tissue; IDs- Inner dictyostele; ODs- Outer dictyostele; Ph- Phloem; SCr- Silica crystal; SL- Scale leaves; TTrichome; Xy- xylem 
Figure 3. Enlarged Dictyostele of Drynaria quercifolia rhizome

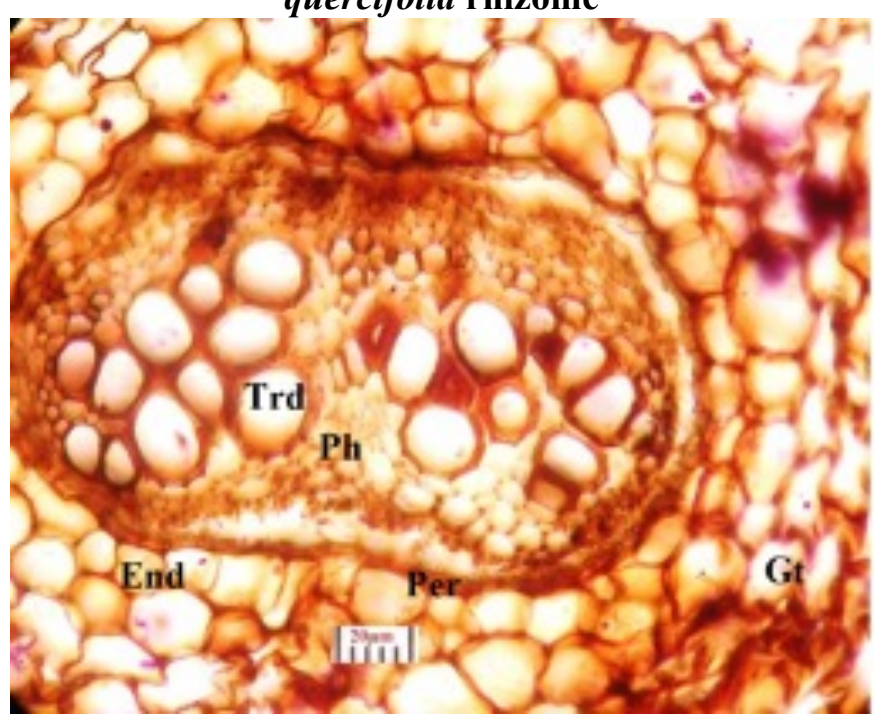

End- Endodermis; F- Fibre; Gt- Ground tissue; PerPericycle; Ph- Phloem; Trd- tracheid

\section{Powder microscopy}

The powdered rhizome is coffee brown in colour with no characteristic odour and a bitter taste. The microscopic investigation of powdered rhizome revealed the presence of epidermal cells of scale leaves, numerous trichomes, parenchyma cells with brownish inclusions and silica crystals, pitted parenchyma cells, normal and pitted fibres, scalariform and reticulate tracheids (Fig 4).

Figure 4. Powder microscopy of Drynaria quercifolia rhizome

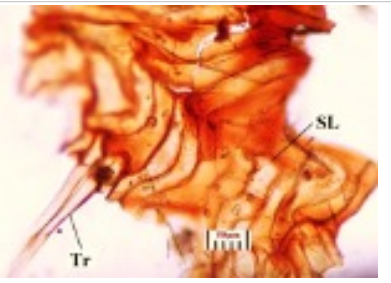

Scale leaves with trichome and oil drops

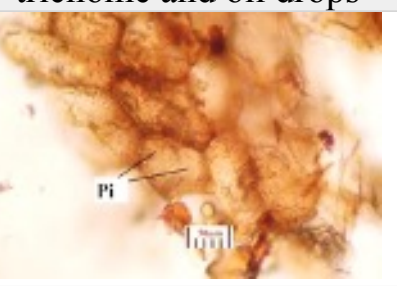

Pitted parenchyma cells with starch grains

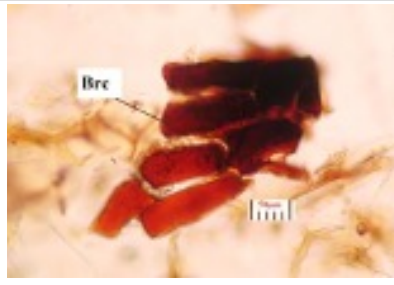

Inner Parenchyma cells filled with tannin

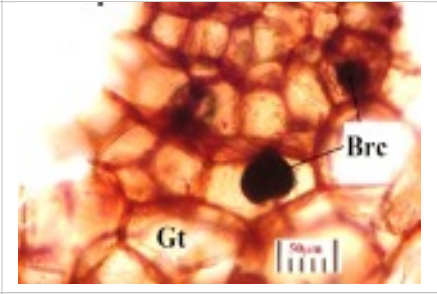

Outer parenchyma cells with brown contents

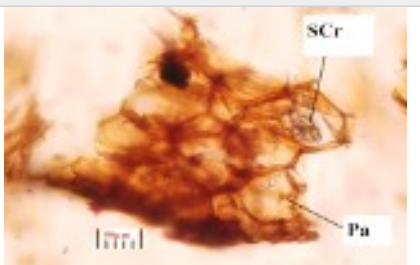

Parenchyma cells with Silica crystals

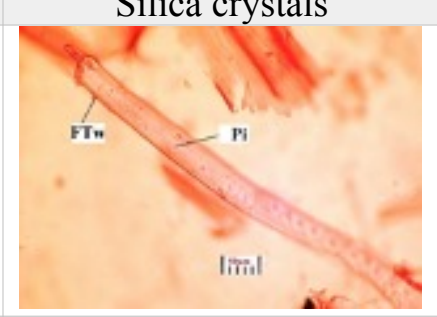

Simple pitted fibretracheids

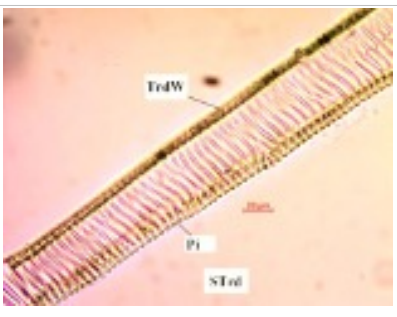

Scalariform tracheid

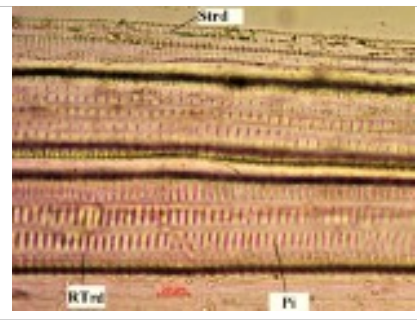

Reticulate tracheids
Brc- Brownish content; FTw- Fibre tracheid wall; Gt-

Ground tissue; Pa- parenchyma; Pi- pits; RTrd-

Reticulated tracheid; SCr- Silica crystal; SL- Scale

Leaves; STrd- Scalariform tracheid; Tr- Trichome; TrdW-Tracheid wall

\section{Physico chemical analysis}

Decrease in the weight of air-dried sample was noticed on drying and was found to be 9.527 at $105^{\circ} \mathrm{C}$. The estimation of the total inorganic content was 8.713. The water soluble ash value was determined and found to be 5.785 and the acid insoluble ash was calculated to be 0.349 . Water soluble extractive was estimated to be 12.595 as compared to 6.429 for ethanol (Table 1).

Table 1. Physicochemical Analysis of Drynaria quercifolia rhizome

\section{Parameters}

Loss on Drying at $105^{\circ} \mathrm{C}$

Total Ash

Acid insoluble Ash

Water soluble Ash

Alcohol soluble extractive

Water soluble extractive

Results $n=3 \%$ w/w Average \pm SD

$9.527 \pm 0.05$

$8.1713 \pm 0.01$

$0.349 \pm 0.07$

$5.785 \pm 0.15$

$6.429 \pm 0.03$

$12.595 \pm 0.50$

Preliminary phytochemical analysis of the sample revealed the presence of alkaloids, carbohydrates, coumarins, flavonoids, tannins and terpenoids while the other phytochemicals were absent (Table 2).

Table 2. Quantitative analysis of phytochemical in Drynaria quercifolia rhizome

\section{Tests \\ Color if positive Inference}

Alkaloids

\begin{tabular}{|l|l|} 
Dragendrof's test Orange precipitate & Present
\end{tabular}

Wagners test

Mayers test

Hagers test

Steroids

Liebermann-

buchard test

Salkowski test

\section{Carbohydrate}

Molish test

Fehlings test

Benedicts test

Tannin

With $\mathrm{FeCl}_{3}$

Red precipitate

Dull white precipitate

Yellow precipitate

\section{Flavonoids}

Shinoda's test

Bluish green

Absent

Bluish red to cherry red

\section{Violet ring}

Brick red precipitate

Red precipitate

Present

Dark blue or green or brown

Present

Red to pink

Present 


\begin{tabular}{|c|c|c|}
\hline \multicolumn{3}{|l|}{ Saponins } \\
\hline With $\mathrm{NaHCO}_{3}$ & Stable froth & Absent \\
\hline \multicolumn{3}{|l|}{ Triterpenoids } \\
\hline $\begin{array}{l}\text { Tin and thionyl } \\
\text { chloride test }\end{array}$ & Pink & Present \\
\hline \multicolumn{3}{|l|}{ Coumarins } \\
\hline With $2 \mathrm{~N} \mathrm{NaOH}$ & Yellow & Present \\
\hline \multicolumn{3}{|l|}{ Phenols } \\
\hline $\begin{array}{l}\text { With alcoholic } \\
\text { ferric chloride }\end{array}$ & $\begin{array}{l}\text { Blue to blue black, } \\
\text { brown }\end{array}$ & Absent \\
\hline \multicolumn{3}{|l|}{ Carboxylic acid } \\
\hline $\begin{array}{l}\text { With water and } \\
\mathrm{NaHCO}_{3}\end{array}$ & Brisk effervescence & Absent \\
\hline \multicolumn{3}{|l|}{ Resin } \\
\hline $\begin{array}{l}\text { With aqueous } \\
\text { acetone }\end{array}$ & Turbidity & Absent \\
\hline \multicolumn{3}{|l|}{ Quinone } \\
\hline $5 \% \mathrm{NaOH}$ & Pink/purple/red & Absent \\
\hline
\end{tabular}

\section{HPTLC}

The fingerprint profile of ethanol extract under $\lambda 254 \mathrm{~nm}$ revealed the presence of only two peaks one at $\mathrm{R}_{\mathrm{f}} 0.63$ with an area of $44.43 \%$ followed by the second at $\mathrm{R}_{\mathrm{f}} 0.76$ with an area of $55.57 \%$; under $\lambda 366$ $\mathrm{nm}$, three peaks appeared at $\mathrm{R}_{\mathrm{f}} 0.51$ with an area $15.1 \%$, second major peak at $\mathrm{R}_{\mathrm{f}} 0.60$ with an area $32.4 \%$ followed by $\mathrm{R}_{\mathrm{f}} 0.80$ with an area of $52.6 \%$; under white light after derivatization, seven peaks were noted viz. at $\mathrm{R}_{\mathrm{f}} 0.02$ with area $9.03 \%, \mathrm{R}_{\mathrm{f}} 0.16$ with area $1.20 \%$; $\mathrm{R}_{\mathrm{f}}$ 0.38 with area $21.64 \%, \mathrm{R}_{\mathrm{f}} 0.48$ with area $45.59, \mathrm{R}_{\mathrm{f}} 0.55$ with area $12.92 \%, \mathrm{R}_{\mathrm{f}} 0.88$ with area $7.73 \%$ and $\mathrm{R}_{\mathrm{f}} 0.97$ with area $1.89 \%$ (Fig. 6 ).

Figure 5. Photo documentation of TLC profile of ethanol extract of Drynaria quercifolia rhizome

\section{TLC}

TLC finger print profile of ethanol extract of Drynaria quercifolia rhizome revealed two bands with $\mathrm{R}_{\mathrm{f}} 0.52$ and 0.69 (light green) under short $\mathrm{UV}(254 \mathrm{~nm})$; 5 spots with $\mathrm{R}_{\mathrm{f}} 0.44$ (fluroscent green), 0.50, 0.65, 0.70 and 0.83 (fluorescent blue) under long UV (366nm); five spots with $\mathrm{R}_{\mathrm{f}} 0.33,0.43$ (dark purple), 0.50 (light purple), $0.79,0.87$ (dark purple) under white light (post derivatization) as seen in Figure 5. Successive densitometric scan showed two bands with $\mathrm{R}_{\mathrm{f}} 0.63$ and 0.76 under short $\mathrm{UV}$; three bands with $\mathrm{R}_{\mathrm{f}} 0.51,0.60$, 0.80 under long $\mathrm{UV}$ and seven bands with $\mathrm{R}_{\mathrm{f}} 0.02,0.16$, $0.38,0.48,0.55,0.88,0.97$ respectively (Fig.5 and Table 3).

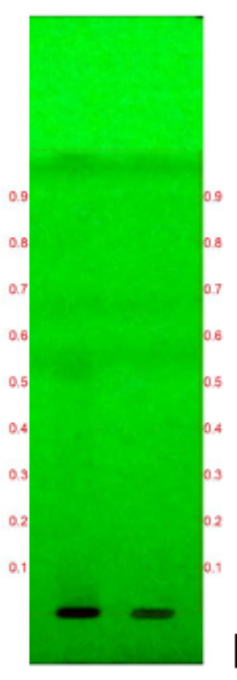

At 254nm

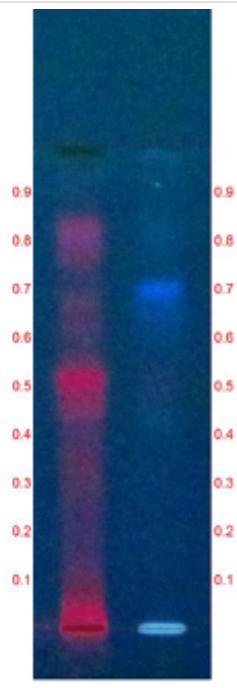

At 366 nm

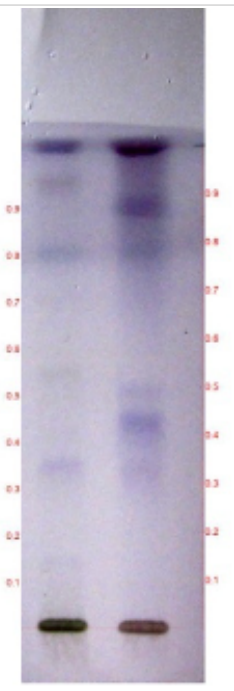

After derivatisation

Table 3. $R_{f}$ values for TLC profile of ethanol extract of Drynaria quercifolia rhizome

\begin{tabular}{|c|c|c|c|c|c|}
\hline \multicolumn{2}{|c|}{ At 254 nm } & \multicolumn{2}{|c|}{ At $366 \mathrm{~nm}$} & \multicolumn{2}{|c|}{ After derivatisation } \\
\hline Colour & $\mathbf{R}_{\mathbf{f}}$ values & Colour & $\mathbf{R}_{\mathrm{f}}$ values & Colour & $\mathbf{R}_{\mathbf{f}}$ values \\
\hline- & - & - & - & D purple & 0.33 \\
\hline- & - & FL green & 0.44 & D purple & 0.43 \\
\hline- & - & FL blue & 0.50 & L purple & 0.50 \\
\hline L green & 0.52 & & - & - & - \\
\hline & - & FL blue & 0.65 & - & - \\
\hline L green & 0.67 & & - & - & - \\
\hline- & - & FL blue & 0.70 & - & - \\
\hline- & - & & - & D purple & 0.79 \\
\hline- & - & FL blue & 0.83 & & - \\
\hline- & - & & - & D purple & 0.87 \\
\hline
\end{tabular}

D - dark; F - fluorescent; L - light (Toluene : Ethyl acetate - 10:1)

Figure 6. Densitometric scans of ethanol extract of Drynaria quercifolia rhizome

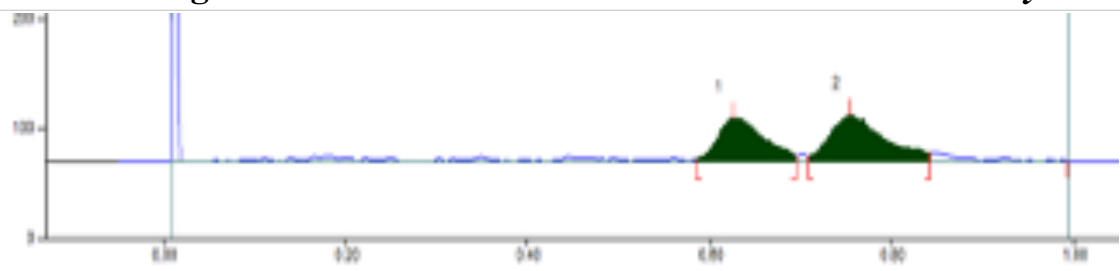

\begin{tabular}{c|c|c|}
\hline $\begin{array}{c}\text { Peak } \\
\mathbf{1}\end{array}$ & $\mathbf{R}_{\mathbf{f}}$ & Area \% \\
\hline & & 44.43 \\
\hline $\mathbf{2}$ & $0.76 \mathrm{Rf}$ & 55.57 \\
\hline
\end{tabular}




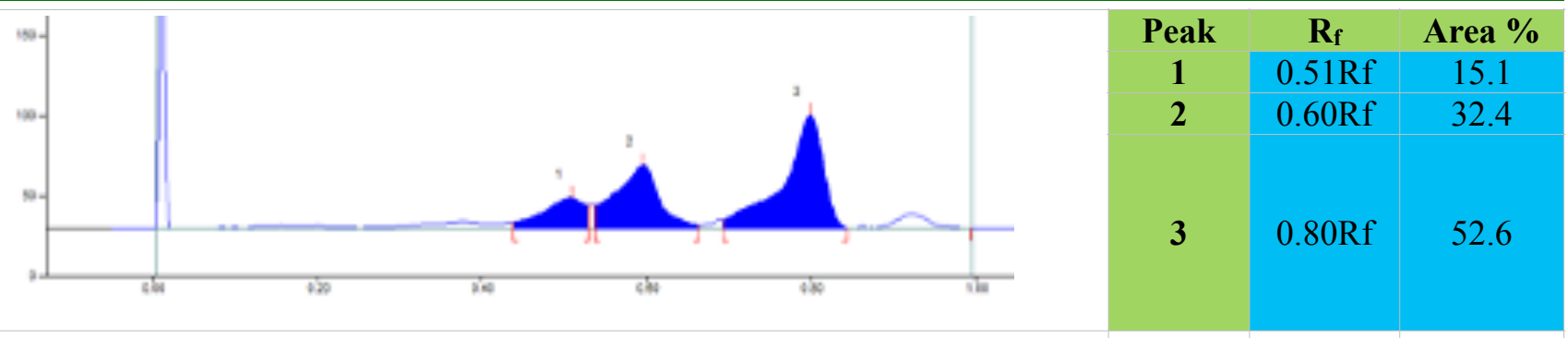

At 366 nm

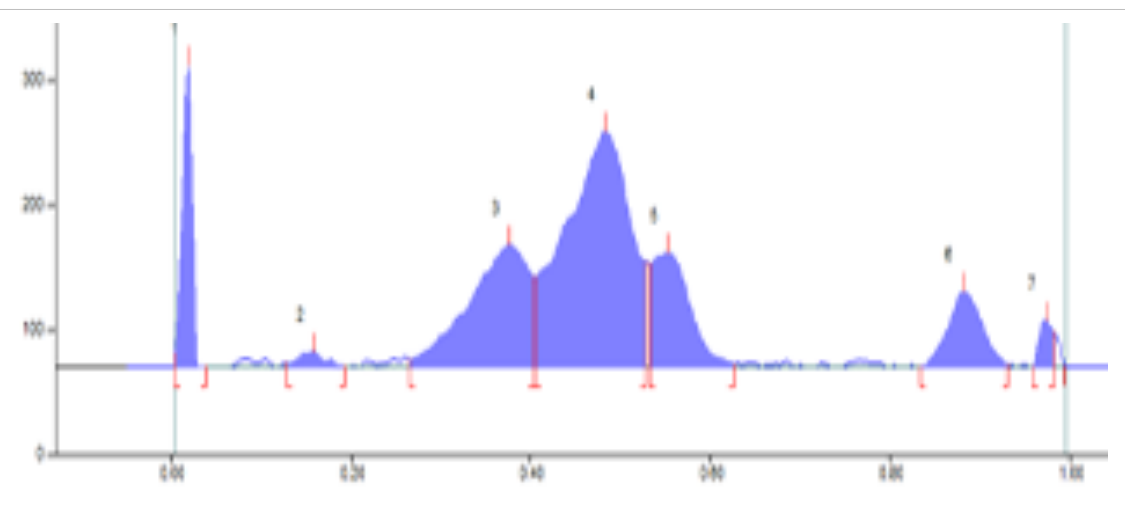

\begin{tabular}{|c|c|c|}
\hline Peak & Rf & Area \% \\
\hline $\mathbf{1}$ & $0.02 \mathrm{Rf}$ & 9.03 \\
$\mathbf{2}$ & $0.16 \mathrm{Rf}$ & 1.20 \\
$\mathbf{3}$ & $0.38 \mathrm{Rf}$ & 21.64 \\
$\mathbf{4}$ & $0.48 \mathrm{Rf}$ & 45.59 \\
$\mathbf{5}$ & $0.55 \mathrm{Rf}$ & 12.92 \\
$\mathbf{6}$ & $0.88 \mathrm{Rf}$ & 7.73 \\
& & \\
\hline $\mathbf{7}$ & $0.97 \mathrm{Rf}$ & 1.89 \\
& & \\
\hline
\end{tabular}

At $620 \mathrm{~nm}$

(Toluene : Ethyl acetate - 10:1)

\section{Discussion}

Evaluation of herbal drugs which confirms its identity and determines its purity has underwent systematic changes over the decades. Due to the variation in the sources of crude drugs, their morphological, biological and chemical nature, different standardization techniques needs to be incorporated for their identification. Rhizomes are functionally perennation organs and contain reserves in parenchyma cells. Macro-microscopy is an important identity determining test in pharmacognostical studies. The transversely cut rhizome surface which is characteristic of every botanical raw drugs aids in its botanical identification (24).

The morphology and anatomy of vascular bundles in fern rhizome remains conserved with a very minimal environmental effects (25). Stelar anatomy probably has a higher some taxonomic significance and could provide information useful to support or further refine details of the recently proposed classifications. The first account of morphological and anatomical studies of Drynaria was carried out by Nayar and Kachroo in1953 (26) and the taxonomic details of Drynaria and Pseudo drynaria were given by Nayar in 1961 (27). Only a fewer pharmacognostical studies has been carried out in Drynaria quercifolia $(28,29)$ which are not as comprehensive as this.

The phytochemical studies carried out by Padmaselvi et al., in 2016 (30) showed the presence of lignins, alkaloids, polyphenols and flavonoids the same has been observed by testing positive for phenols in the present study. The total ash value $9.93 \%$, acid insoluble ash value $4.49 \%$ water soluble ash value $6.69 \%$ alcohol extractive value $9.87 \%$ and water extractive value was 13.94\% was determined by Prakash et al., (2010) (31), during their study which can be correlated to the present study with a minimal variations.

The anatomical sections showed the presence of scales, diffused dictyostele, broad ground tissue which is in similarity with the study of Nayar and Kachroo (26). The powder microscopic analysis of the drug showed comparatively more diagnostic features when compared to the study of Janarthan et al. (29).

TLC of D. quercifolia carried out in the present study gave similar results to the previous work (31). The HPTLC profiling of the D. quercifolia rhizome revealed the presence of blue fluorescent band at 366 $\mathrm{nm}$ before derivatisation which can be accredited to the presence of triterpenes and can be very well related to the previous studies of Nejad and Deokule in 2009 (16).

Prasana and Chithra have reported the GC MS analysis of D. quercifolia rhizome (32). Medico folklore studies incorporating the different therapeutic usage of this fern have been carried out by few workers $(33,34)$. Earlier studies on antibacterial and antifungal (35), antioxidant (36), anti-inflammatory (37), anti-diabetic (38), anti-dermatophytic (16), anti-urolithiatic (39), and wound healing (40) activities has also confirmed the important bioactivities and medicinal attribute of this fern. Even the present study substantiated the presence of phyto constituents like alkaloids, coumarins, tannins, terpinoids and flavonoids which imparts the bioactivities.

\section{Conclusion}

The non-flowering plants are endowed with immense medicinal properties. The rhizome of Drynaria quercifolia is used in the treatment of various ailments and the present comprehensive pharmacognostic study revealed the morphological, 
microanatomical and phytochemical aspects of this medicinal rhizome. Thus, the study provides an inclusive distinctive pharmacognostical profile of this pteridophytic rhizome.

\section{Acknowledgements}

The authors express their heartfelt thanks to the Director General, CCRS for the support.

\section{References}

1. https://www.gbif.org/occurrence/search? has_coordinate $=$ true $\&$ has_geospatial_issue $=$ fal 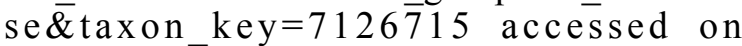 24/06/2020, time 14:30 IST

2. Kirtikar K.R. and Basu B.O. Indian medicinal plants, Bishen Singh Mahendra Pal Singh, Dehra Dun. Vol.4 (Fern), 1935, 1918 \& 2747-1989 reprints. Pp. 2747.

3. Warrier P.K, Nambiar V.P, Ramankutty C. Indian medicinal plants: a compendium of 500 species, volume 2: Orient Longman Ltd. Chennai. 1996; 3:38-90.

4. Ramesh N, Viswanathan M.B, Saraswathy A, B a lakrishna K, Brindha P, Lakshmanaperumalsamy P. Phytochemical and Antimicrobial Studies on Drynaria quercifolia. Fitoterapia 2001;72:934-936.

5. Mollik A.H, Hasan N, Hossan S, Jahan R, Rahmatullah M. Medicinal plants used against malaria in several regions of Bogra district, Bangladesh. Planta Med 2009;75:39.DOI: 10.1055/s-0029-1234518.

6. Rahman M.A, Uddin S.B, Wilcock C.C. Medicinal Plants used by Chakma tribe in Hill Tracts districts of Bangladesh. Indian $\mathrm{J}$ Trad Know 2007;6:508-517.

7. Rahmatullah M, Mukti I. J, Haque A.K.M, Mollik M.A.H, Parvin K, Jahan R, Chowdhury M.H, Rahman, T. An Ethnobotanical Survey and Pharmacological Evaluation of Medicinal Plants used by the Garo Tribal Community living in Netrakona district, Bangladesh. Adv Nat App Sci 2009;3:402-418.

8. Rahmatullah M, Jahan R, Seraj S, Islam F, Jahan F.I, Khatun Z, Sanam S, Monalisa M.N, Khan T, Biswas K.R. Medicinal Plants Used by Folk and Tribal Medicinal Practitioners of Bangladesh for Treatment of Gonorrhea, Am Euras J Sust Agric 2011;5:358-363.

9. Rahmatullah M, Azam N.K, Khatun Z, Seraj S, Islam F, Rahman A, Jahan S, Aziz S. Medicinal plants used for treatment of diabetes by the marakh sect of the Garo tribe living in Mymensingh district, Bangladesh. Afri J Trad Comp Alt Med 2012;9:380-385.

10. Rahim Z.B, Rahman M.M, Saha D, Hosen S.M.Z, Paul S, Kader S.Etnomedicinal plants used against Jaundice in Bangladesh and its economical prospects. Bul Pharmac Res 2012;2:91-105.

11. Khan A., Haque E., Rahman B.M, Rahman M. Neuropharmacological Effect of the Rhizome of Drynaria quercifolia in Mice. Iran J Pharm Therapy 2009;8:23-27.

12. Sarker S.K, Hossain, A.B.M.E. Pteridophytes of greater Mymensingh district of Bangladesh used as Vegetables and Medicines. Bangladesh J Plant Taxon 2009; 16:47-59.

13. Holttum, R.E. A Revised Flora of Malaya and Ferns of Malaya. Government Singapore 1997:2:275-279.

14. Das H.B, Majumdar K, Datta B.K, Ray D. Ethnobotanical uses of some plants by Tripuri and Reang tribes of Tripura. Nat Prod Rad 2009;8:172-180.

15. Samydurai P, ThangapandianV., Aravinthan V, Wild habitats of Kolli Hills being stale food of inhabitant tribes of eastern Ghats, Tamil Nadu, India. Indian J Nat Prod Res 2012;3:432-437.

16. Nejad, B.S., Deokule, S.S., Anti-dermatophytic activity of Drynaria quercifolia (L.) J. Smith. Jundishapur J Microbiol 2009;2:25-30.

17. Sutha S, Mohan V.R, Kumaresan S., Murugan C., Athiperumalsamy T. Ethnomedicinal plants used by the tribals of Kalakad-Mundanthurai Tiger Reserve (KMTR), Western Ghats, Tamil Nadu for the treatment of rheumatism. Indian J Tradit Knowledge 2010;9:502-509.

18. Bose D, Roy J.G, Mahapatra S.D, Datta T, Mahapatra S.D, Biswas H. Medicinal plants used by tribals in Jalpaiguri district, West Bengal, India. J Med Plants Stud 2015;3:15-21

19. Udayan P.S, Satheesh G, Thusar K.V, Indira B. Medicinal plants used by Kadar tribes in Sholayar forest, Thrissur district, Kerala, Int J Trad Med 2005; 4(2):159-163.

20. Bhuvaneswari R, Ramanathan R, Krishnapriya P, Madheswaran A, Dhandapani R. Survey of wild tuberous medicinal plants of Kolli hills in Namakkal district, Tamil Nadu, India. Int J Herb Med 2015;3(4):41-8.

21. Quality control Methods for medicinal plant materials. World Health Organizing, Geneva. 1998.

22. Divya K.G, Rubeena M, Sundaramoorthy B, Bobbili E, Remya A, Sunil Kumar K.N. Macromicroscopic profiling of Azinjil, Aavaram and Marukkaraiverpattai (root bark) of Siddha. Int J Res Ayurveda Pharm 2018; 9(4):62-69

23. The Ayurvedic Pharmacopoeia of India. Part-I, Vol II, 1st ed., Ministry of Health and family welfare, New Delhi; Department of Indian system of medicine and Homeopathy, 1999; 183-196.

24. Wallis T.E. Text book of Pharmacognosy, New Delhi; CBS Publishers and Distributors, 2005; pp.111-17, 352-53,561-63.

25. Srivastava A, Chandra S. Structure and organization of the rhizome vascular system of four Polypodium species. American Fern Journal 2009;99(3):182-93.

26. Nayar BK, Kachroo P. Studies in Polypodiaceae. I. Contributions to the morphology of DrynariaBory: D. quercifolia 
(L.) J.bm. and D. propinqua (Wall.) J.Sm. Phytomorphology 1953;3:11-423.

27. Nayar, B. K - Ferns of India. No. 2. Drynaria and Pseudodrvnaria. Ibid. No. 56:1961; 1-30.

28. Kamboj P, Kalia A. N. Morphoanatomical and physico-chemical standardization of Drynaria quercifolia (L.) J. Smith. World J Pharm Pharm Sci 2014; 3(4): 696-711.

29. Janarthanan L, Karthikeyan V, Balakrishnan B. R, Jaykar B, Senthilkumar K. L, Anandharaj G. Pharmacognostical standardization and phytochemical profile of rhizomes of Drynaria quercifolia (Linn) J. Smith. European Journal of Biomedical and Pharmaceutical Science 2016;3(8):278-287.

30. Padma Selvi B, PrasannaG, Anuradha R. Physicochemical and phytochemical analysis of the rhizome of Drynaria quercifolia L. IJPR 2016;7(1):18- 22.

31. Prakash G, Korwar, Arun Kumar Beknal, Basawaraj S, Patil M.A, Halkai, UpendraKulkarni, Hariprasanna R.C. and Srinivas R.S. A study on phytochemical investigation of Drynaria quercifolia linn rhizome. Int J Pharm Sci Res 2010;1(12): 148-158.

32. Prasanna G, Chitra M. Phytochemical screening and GC-MS Analysis of Drynaria quercifolia Rhizome. Am J Adv Drug Delivr 2015;3(1):72-8.

33. Padhy R, Dash SK. Medico-folklore study on some Pteridophytes from Kerandimal Hills of South Odisha with emphasis on Drynaria quercifolia (Linn.) J. Smith. Res J o Pharm Biol Chem Sci 2015;6(4):2029-35.
34. Benjamin A. and Manickam, V.S. Medicinal pteridophytes from the Western Ghats. Indian Journal of Traditional Knowledge. 2007;6(4).611-18.

35. Pargavi B, Sivakumar T. Phytochemical screening and antimicrobial activity of Drynaria quercifolia (L.) J. Smith. Int J Curr Res Chem and Pharm Sci 2014;1(5): 68-73.

36. Jinu U, Tha. Thayumanavan, Thakur Balwant Singh, SasikumarJ.M. In vitro Antioxidant capacity of the Fern, Drynaria quercifolia (L) SM., rhizome extract. Int $\mathrm{J}$ Pharm Pharm Sci 2014; 6(7): 413-416.

37. Prasanna G, Chitra $\mathrm{M}$. In vitro antiinflammatory activity of Drynaria quercifolia rhizome. Research $\mathbf{J}$ of Pharmacognosy and Phytochemistry 2015;7(1):6-8.

38. Rajimol E.K, Shan P Mohammed, Nasiya Latheef P, Sriganesan. Evaluation of Antidiabetic and Hypolipidemic Potential of Drynaria quercifolia Linn Rhizome in Streptozotocin Induced Diabetic Rats. Int J Pharm Sci Rev Res 2014;25(1):118-24.

39. Mazumder P.B, Bonani Mazumder, Dutta Choudhury M, Sharma GD. In vitro Propagation of Drynaria quercifolia (L.) J. Sm., a Medicinal Fern. Assam University Journal of Science \& Technology: Biological and Environmental Sciences 2011;7 (I):79-83.

40. Ranjan P, Santosh Kumar D, Sunita P, Sanjeeb Kumar P. Studies on healing activity Vis-à-vis microflora of acute induced wounds against solvent extracts of rhizome of Drynaria quercifolia Linn. J Pharm Biol Sci 2014; 9(5): $38-49$. 